\title{
COX-2 expression in papillary thyroid carcinoma (PTC) in cytological material obtained by fine needle aspiration biopsy (FNAB)
}

Kinga Krawczyk-Rusiecka, Katarzyna Wojciechowska-Durczyńska, Anna Cyniak-Magierska, Zbigniew Adamczewski, Elżbieta Gałecka, Andrzej Lewiński*

\begin{abstract}
Background: COX-2 is an enzyme isoform that catalyses the formation of prostanoids from arachidonic acid. An increased COX-2 gene expression is believed to participate in carcinogenesis. Recent studies have shown that COX2 up-regulation is associated with the development of numerous neoplasms, including skin, colorectal, breast, lung, stomach, pancreas and liver cancers. COX-2 products stimulate endothelial cell proliferation and their overexpression has been demonstrated to be involved in the mechanism of decreased resistance to apoptosis. Suppressed angiogenesis was found in experimental animal studies as a consequence of null mutation of COX-2 gene in mice. Despite the role of COX-2 expression remains a subject of numerous studies, its participation in carcinogenesis or the thyroid cancer progression remains unclear.

Methods: Twenty three (23) patients with cytological diagnosis of PTC were evaluated. After FNAB examination, the needle was washed out with a lysis buffer and the obtained material was used for COX-2 expression estimation. Total RNA was isolated (RNeasy Micro Kit), and RT reactions were performed. $\beta$-actin was used as endogenous control. Relative COX-2 expression was assessed in real-time PCR reactions by an ABI PRISM 7500 Sequence Detection System, using the $\Delta \Delta C_{T}$ method.
\end{abstract}

Results: COX-2 gene expression was higher in patients with PTC, when compared to specimens from patients with non-toxic nodular goitre (NTG).

Conclusions: The preliminary results may indicate COX-2 role in thyroid cancer pathogenesis, however the observed variability in results among particular subjects requires additional clinical data and tumor progression analysis.

\section{Background}

The most common thyroid malignancy is papillary thyroid carcinoma (PTC), accounting for approximately $85-90 \%$ of all thyroid cancers. PTC usually grows slowly and is clinically indolent, although aggressive forms can also occur. The 10-year survival rate for all PTC patients is estimated at $80-90 \%$ [1].

The introduction of fine-needle aspiration biopsy (FNAB) has made PTC identification more accurate, but still the diagnostic tools regarding the differentiation between thyroid benign and malignant lesions are not

\footnotetext{
* Correspondence: alewin@csk.umed.lodz.pl

Department of Endocrinology and Metabolic Diseases, Medical University of Lodz, Polish Mother's Memorial Hospital - Research Institute, Lodz, Poland
}

always reliable. The molecular basis of PTC has been examined and association with variety of molecular prognostic markers has been described, including $R A S$, RET, Trk, MET, and BRAF mutations [2].

Cyclooxygenase-2 (COX-2) is an enzyme isoform involved in the conversion of arachidonic acid to prostaglandin $\mathrm{H}_{2}$, the precursor of various molecules, including prostaglandins, prostacyclines and thromboxanes. COX-2 can be expressed in response to various stimuli, such as hormones, mitogens, cytokines, inflammatory mediators and growth factors via protein kinase $\mathrm{C}$ and RAS-mediated signaling $[3,4]$. The products of COX-2 activity are believed to be involved in carcinogenesis by promoting angiogenesis, inhibiting apoptosis, increasing
C Biomed Central

() 2011 Krawczyk-Rusiecka et al; licensee BioMed Central Ltd. This is an Open Access article distributed under the terms of the Creative Commons Attribution License (http://creativecommons.org/licenses/by/2.0), which permits unrestricted use, distribution, and reproduction in any medium, provided the original work is properly cited. 
cell invasion and stimulating cell proliferation. COX-2 also modulates vascular endothelial growth factor (VEGF) production, the factor that promotes angiogenesis and decreases immunity toward cancer cells [5-9].

Recent studies have highlighted the relevance of COX-2 in human carcinogenesis. Increased levels of COX-2 have been reported in numerous tumours, including head and neck squamous cell cancer, as well as colorectal, breast, lung, skin, stomach, liver, pancreas, bladder, ovaries and prostate carcinomas [10-19].

Selective inhibition of COX-2 is a novel therapy under investigation in both the chemoprevention and treatment of solid tumors [20,21]. Experimental animal data indicate that $C O X-2$ gene may be associated with carcinogenesis of several types of human malignancies.

Whether COX-2 expression is related to the morphology of PTC remains unclear. In the present study we have investigated COX-2 expression in 23 cases of PTC diagnosed cytologically following FNAB.

\section{Methods}

45 thyroid specimens were analyzed, i.e. 23 cases of PTC and 22 cases of benign thyroid lesions; 6 men and 39 women participated in the study. Patients ranged in age from 24 to 87 years (median - 48 years in PTC group, 58 years in benign thyroid lesions group). Thyroid aspirates, eligible for the study, were obtained from patients by fine needle aspiration biopsy (FNAB) in the Clinical Hospital No. 3, Medical University of Lodz (2007-2010). Each aspirate was smeared for conventional cytology, while the remaining part of aspirate was immediately washed out of the needle. The cells, obtained from the needle, were used in further investigation. Macroscopically unchanged thyroid tissue, collected from patients treated surgically, was used as an internal control.

The procedures, used in the study, were approved by the Ethical Committee of the Medical University of Lodz (Poland). All patients were informed and agreed to participate in this study.

Total RNA was extracted using RNeasy Micro Kit (Qiagen, Hilden, Germany), based on modified Chomczyński and Sacchi's method [22]. RNA concentration was spectrophotometrically assessed by measuring absorbance at 260 and $280 \mathrm{~nm}$ (NanoDrop ND-1000 Spectrophotometer, Thermo Fisher Scientific, USA).

Total RNA was reversely transcribed in a Mastercycler personal thermocycler (Eppendorf, Hamburg, Germany), according to manufacturer's procedures in a total volume of $50 \mu \mathrm{l}$ including oligo $\mathrm{d}(\mathrm{T}) 16(50 \mu \mathrm{M})$, MultiScribe Reverse Transcriptase $(50 \mathrm{U} / \mu \mathrm{l}), 10 \times$ TaqMan RT Buffer, $\mathrm{MgCl}_{2}$ solution ( $25 \mathrm{mM}$ ), dNTPs mixture $(10 \mathrm{mM})$, RNAse Inhibitor $(20 \mathrm{U} / \mu \mathrm{l})$ and nuclease-free water (TaqMan Reverse Trancriptase Reagents, Applied
Biosystems, CA, USA). The reactions were incubated for $10 \mathrm{~min}$ in $25^{\circ} \mathrm{C}, 30 \mathrm{~min}$ in $48^{\circ} \mathrm{C}$, heated for $5 \mathrm{~min}$ in $95^{\circ} \mathrm{C}$ and placed at $4^{\circ} \mathrm{C}$.

The relative expression of $C O X-2$ gene was assessed, using the ABI PRISM 7500 SDS Software (ABI PRISM 7500 Sequence Detection System, Applied Biosystems), according to the manufacturer's protocol. The PCR reactions for COX-2 gene were run with $5 \mu \mathrm{l}$ of cDNA in a total volume of $50 \mu \mathrm{l}$, using TaqMan Universal PCR Master Mix (Applied Biosystems, Foster City, CA, USA) and predesignated primer/probe set (Assays-on-Demand ${ }^{\mathrm{m}}$ Gene Expression assay, Hs 00153133_m1, Applied Biosystems). Amplification reactions were done in triplicate for each examined sample.

Controls with no template cDNA were used with each assay. The reference gene was $\beta$-actin (Assays-onDemand $^{\mathrm{mT}}$ Gene Expression assay, Hs 99999903_m1, Applied Biosystems). Samples of cDNA were quantified using a fluorescence based real-time detection method (TaqMan).

Assays-on-Demand Gene Expression product consists of $20 \times$ mix of unlabelled PCR primers and TaqMan MGB probe $(5 \mu \mathrm{M})$ with $\mathrm{FAM}^{\mathrm{sm}}(6$-carboxy-fluorescein) at the 5 ' end as the reporter dye and a non-fluorescent quencher (TAMRA, 6-carboxy-tetramethylrhodamine) at the $3^{\prime}$ end. Cycling conditions were $50^{\circ} \mathrm{C}$ for $2 \mathrm{~min}$ and $95^{\circ} \mathrm{C}$ for 10 minutes, followed by 50 cycles at $95^{\circ} \mathrm{C}$ and $60^{\circ} \mathrm{C}$ for 1 minute. A sample of normal thyroid tissue served as a calibrator to compare the relative amount of target in different samples and to adjust for the plateto-plate variation in amplification efficiency.

\section{Data and statistical analysis}

Relative gene expression - determined by comparing threshold cycle $\left(\mathrm{C}_{T}\right)$ for gene of interest (COX-2) with $\mathrm{C}_{T}$ for the reference gene ( $\beta$-actin) - was calculated using the $\Delta \Delta C_{T}$ method as described previously [23]. The characteristics, RQ and $\Delta C_{T}$ values of patients groups are shown in Table 1 and Table 2.

Statistical analysis was performed, using a standard parametric Student's t test, followed by non-parametric U Mann-Whitney's test. P values $<0.05$ were considered to indicate statistical significance.

\section{Results}

COX-2 mRNA expression was significantly higher in PTC when compared to benign thyroid lesions (Student's t-test, $P=0.021$ ). There was no significant relationship between $C O X-2$ expression and patients age and sex. The amplification plots of $C O X-2$ and $\beta$-actin are shown in Figure. 1 and 2. The statistical analysis of COX-2 expression by quantitative Real Time PCR in PTC and NTG is presented in Figure. 3 and Figure. 4. 
Table 1 Gender, age, ddCT and RQ values in PTC group

\begin{tabular}{|c|c|c|c|c|}
\hline No. & Gender & Age & ddCT & $\mathrm{RQ}$ \\
\hline 1. & M & 56 & -0.84 & 1.79 \\
\hline 2. & M & 64 & -0.71 & 1.63 \\
\hline 3. & $\mathrm{~F}$ & 52 & -6.49 & 89.8 \\
\hline 4. & $\mathrm{~F}$ & 28 & 0.95 & 0.52 \\
\hline 5. & $F$ & 53 & -1.62 & 3.06 \\
\hline 6. & $M$ & 61 & -0.62 & 1.53 \\
\hline 7. & $\mathrm{~F}$ & 57 & -2.46 & 5.49 \\
\hline 8. & $\mathrm{~F}$ & 36 & -4.07 & 16.74 \\
\hline 9. & $\mathrm{~F}$ & 56 & -2.76 & 6.77 \\
\hline 10. & $M$ & 58 & -3.12 & 8.69 \\
\hline 11. & $\mathrm{~F}$ & 28 & 1.31 & 0.4 \\
\hline 12. & $\mathrm{~F}$ & 24 & -1.31 & 2.48 \\
\hline 13. & $F$ & 67 & -1.51 & 2.84 \\
\hline 14. & $\mathrm{~F}$ & no data & 1.24 & 2.36 \\
\hline 15. & $F$ & 39 & -2.0 & 4.01 \\
\hline 16. & $\mathrm{~F}$ & 49 & -0.75 & 1.68 \\
\hline 17. & $\mathrm{~F}$ & 28 & 2.86 & 0.14 \\
\hline 18. & $F$ & 45 & -2.75 & 6.73 \\
\hline 19. & $\mathrm{~F}$ & 50 & -2.11 & 4.31 \\
\hline 20. & $\mathrm{~F}$ & 63 & -0.86 & 1.82 \\
\hline 21. & $M$ & 53 & -3.98 & 15.8 \\
\hline 22. & $\mathrm{~F}$ & 39 & -3.44 & 10.84 \\
\hline 23. & $\mathrm{~F}$ & 49 & -2.22 & 4.66 \\
\hline
\end{tabular}

\section{Discussion}

The relation between $\mathrm{COX}-2$ activity and carcinogenesis is being examined in variety of human neoplasms. Fine needle aspiration biopsy has become a critical diagnostic tool in management of thyroid nodules. It has allowed to decrease the number of cases inquiring surgical treatment from $67 \%$ to $44 \%$; also the percentage of operated carcinomas in those nodules has increased from $14 \%$ to $29 \%$ [24]. Generally, preoperative discrimination of the thyroid malignancy, using not only cytopathology but also molecular markers, would enhance the proper diagnosis.

In our study, COX-2 expression in both NTG and PTC were examined. COX-2 expression was significantly higher in PTC group.

All but one of the previously conducted studies found overexpression of COX-2 in cases of PTC and follicular thyroid carcinoma (FTC). In the study of Ito et al. [25], there were 9 COX-2-negative $(18,4 \%)$ among 49 of PTC cases, studied by immunochemistry. They also suggested significant reduction of COX-2 levels in older patients (over 54 years old), in patients with large tumors and with the advanced disease stages, as well as with the presence of solid, scirrhous or trabecular growth
Table 2 Gender, age, ddCT and RQ values in NTG group

\begin{tabular}{|c|c|c|c|c|}
\hline No. & Gender & Age & ddCT & $\mathrm{RQ}$ \\
\hline 1. & F & 27 & -0.84 & 1.79 \\
\hline 2. & $\mathrm{~F}$ & 87 & -0.41 & 1.32 \\
\hline 3. & $\mathrm{~F}$ & 65 & 1.98 & 0.25 \\
\hline 4. & $F$ & 72 & -1.01 & 2.02 \\
\hline 5. & $\mathrm{~F}$ & 64 & -2.32 & 4.71 \\
\hline 6. & $F$ & 68 & -0.01 & 1.01 \\
\hline 7. & $\mathrm{~F}$ & 46 & -2.07 & 4.21 \\
\hline 8. & $\mathrm{~F}$ & 39 & 1.55 & 0.34 \\
\hline 9. & $M$ & 56 & -0.63 & 1.55 \\
\hline 10. & $\mathrm{~F}$ & 68 & -0.98 & 1.98 \\
\hline 11. & $F$ & 62 & 2.94 & 0.13 \\
\hline 12. & $F$ & 48 & 1.96 & 0.26 \\
\hline 13. & $\mathrm{~F}$ & 32 & -2.91 & 7.51 \\
\hline 14. & $M$ & 61 & -0.21 & 1.15 \\
\hline 15. & $F$ & 29 & 0.74 & 0.6 \\
\hline 16. & $\mathrm{~F}$ & 88 & -0.68 & 1.6 \\
\hline 17. & $M$ & 71 & -1.53 & 2.88 \\
\hline 18. & $\mathrm{~F}$ & 43 & -0.46 & 1.37 \\
\hline 19. & $\mathrm{~F}$ & 54 & 0.77 & 0.24 \\
\hline 20. & $\mathrm{~F}$ & 50 & -1.2 & 2.3 \\
\hline 21. & $F$ & 79 & -1.37 & 2.59 \\
\hline 22. & $\mathrm{~F}$ & 71 & -0.93 & 1.9 \\
\hline
\end{tabular}

pattern. An association among and age and worse prognosis has been well-recognized in the medical literature. Accordingly, Ito et al. [25] found that the COX-2 levels were significantly reduced in older patients, whereas Siironen et al. [26] demonstrated the older age group of patients, having a much worse prognosis and higher COX-2 levels. However, in our study, we have failed to establish statistical significance between COX-2 expression and patients' age or sex which is similar to results of Garcia-Gonzales et al [27].

The results of Kajita et al. [28] did not show any significant differences in COX-2 expression between normal thyroid tissue and PTC, because of variation in mRNA levels. The authors have also performed the in vitro study, with the TPC-1 thyroid carcinoma cell line and a compound NS-398 - a COX-2 enzymatic activity specific inhibitor, showing inhibited growth of tumor cells. They concluded the role of COX-2 in the growth of PTC cell lines.

Cornetta et al. [29] examined a variety of thyroid tissue specimens; COX-2 staining was not observed in none of the 6 specimens obtained from normal or multinodular goiter specimens. Analysis of Hashimoto's thyroiditis revealed COX-2 expression in the follicular epithelium and lymphocytic infiltrates, as well as in cases of FTC and PTC [29]. 


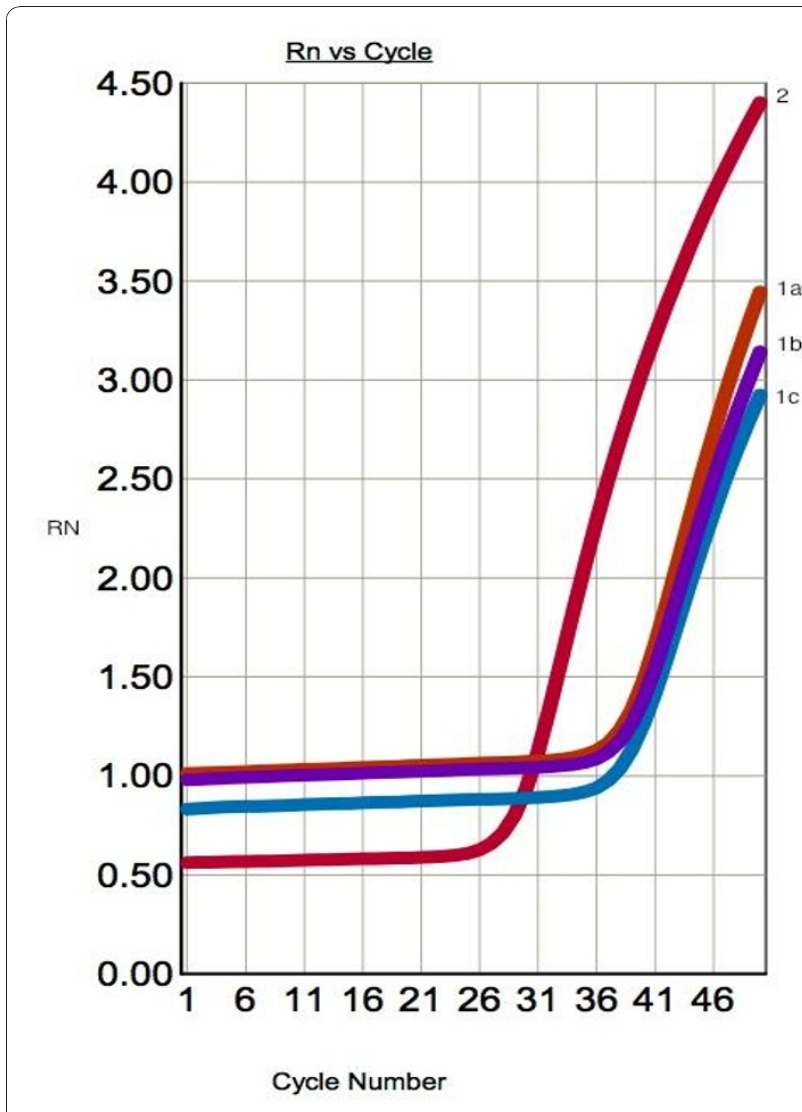

Figure 1 Representative amplification curves for COX-2 and $\beta$-actin genes in real-time PCR in PTC specimen. $1 \mathrm{a}, \mathrm{b}, \mathrm{c}$ amplification curve for COX-2 gene (mean $C_{T}$ value - 36.694); 2 amplification curve for $\beta$-actin gene (endogenous control) (mean $C_{T}$ value - 27.071).

The study of Lee et al. [30] showed prominent expression of COX-2 in thyroiditis, benign and malignant thyroid lesions but not in normal thyroid tissues. They also observed no correlation between severity of PTC, regardless of the presence or absence of metastases. Because of the same intensity of COX-2 staining, found in thyroiditis, benign and malignant thyroid lesions the authors concluded that it is unlikely that COX-2 expression is related to the progression of thyroid disease.

The results of study with $A p c^{\Delta 716}$ knockout mice [31], suggested that the induction of $C O X-2$ was a very early event in colon carcinogenesis. This view has been supported by Garcia-Gonzales et al. [28] who have suggested that even though COX-2 plays an important role in progression of all thyroid cancers, in case of PTC it seems to be more important only in the early stages of disease.

\section{Conclusions}

The usefulness of $C O X-2$ as a marker of thyroid malignancy has been challenged but its potential role in
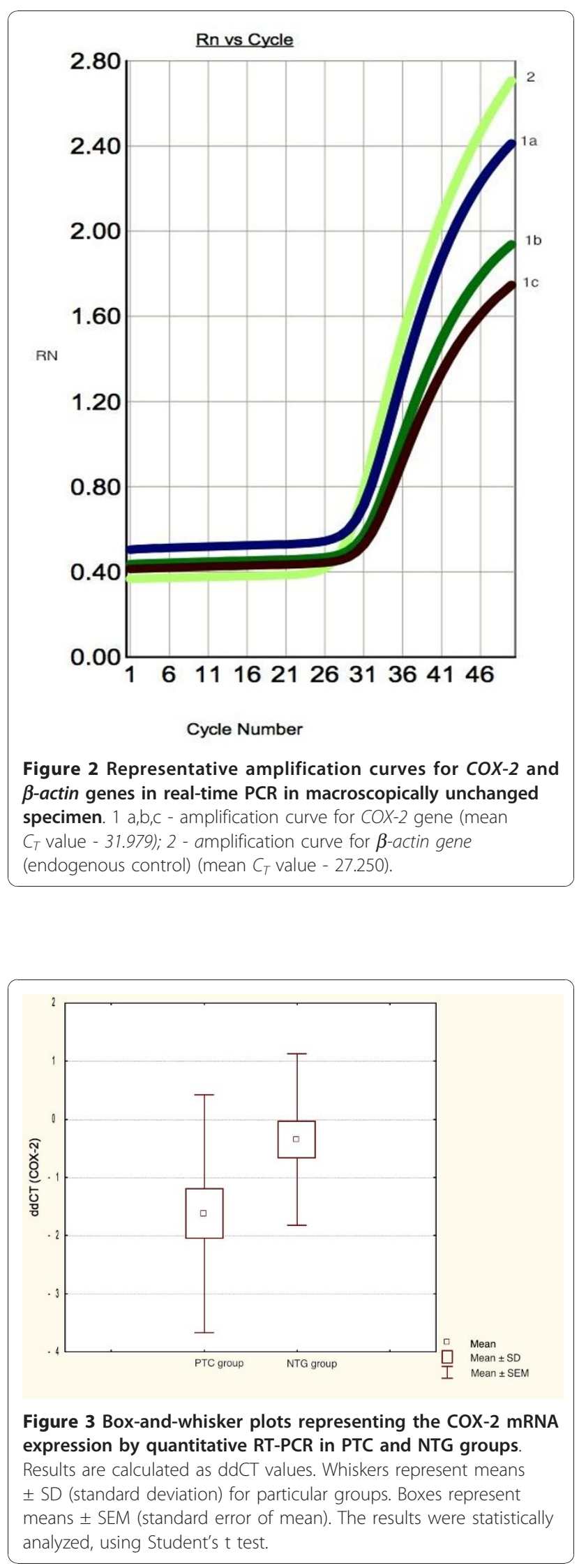


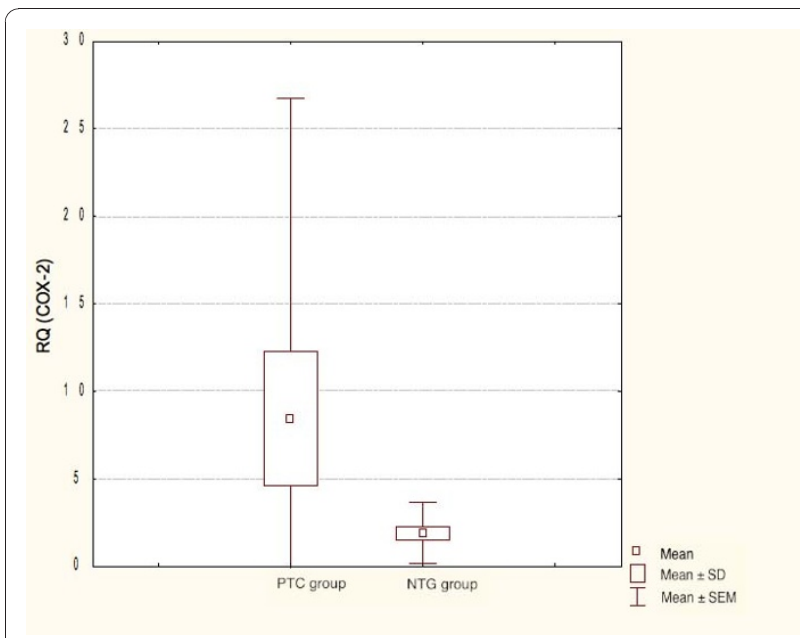

Figure 4 Box-and-whisker plots representing the COX-2 mRNA expression by quantitative RT-PCR in PTC and NTG groups Results are calculated as $R Q$ values. Whiskers represent means $\pm S D$ (standard deviation) for particular groups. Boxes represent means \pm SEM (standard error of mean). The results were statistically analyzed, using Man-Whitney's $U$ test $(p<0.05)$.

carcinogenesis arouses significant interest. In the present study, COX-2 expression was found in all studied samples and the elevated level of $C O X-2$ gene expression was confirmed in PTC genetic material, collected from the fine-needle washout fluids. Thus, $C O X-2$ gene may play a significant role in the pathogenesis of this cancer type. Furthermore, COX-2 gene overexpression levels were individually diversified, what may have resulted from their association with different genetic and clinical prognostic factors.

\section{Acknowledgements}

This study was supported by the funds of the Medical University of Lodz Grant No. 502-11-843 and of the Ministry of Scientific Research and Information Technology of Poland - Grant No 1296/B/P01/2009/37. The publication of the above article was financially supported by the Ministry of Science and Higher Education of Poland - the grant of the Polish Thyroid Association.

\section{Authors' contributions}

KK-R designed and coordinated the study, carried out the molecular genetic studies and drafted the manuscript. KW-D participated in performing molecular studies. AC-M participated in performing molecular studies. ZA and EG participated in coordination of molecular genetic studies. AL, the senior author, wrote the manuscript. All authors read and approved the final manuscript.

\section{Competing interests}

The authors declare that they have no competing interests.

Received: 8 December 2010 Accepted: 10 January 2011

Published: 10 January 2011

\section{References}

1. Sheils O: Molecular classification and biomarker discovery in papillary thyroid carcinoma. Expert Rev Mol Diagn 2005, 6:927-946.
2. Lewiński A, Wojciechowska K: Genetic background of carcinogenesis in the thyroid gland. Neuroendocrinol Lett 2007, 28:77-105.

3. Wirtschafter A, Schmidt R, Rosen D, Kundu N, Santoro M, Fusco A, Multhaupt H, Atkins JP, Rosen MR, Keane W, Rothstein JL: Expression of RET/PTC gene as a marker for papillary thyroid carcinoma on Hashimoto's thyroiditis. Laryngoscope 1997, 107:95-100.

4. Califano D, Rizzo C, D'Alessio A, Colucci-D'Amato GL, Cali G, Bartoli PC, Santelli G, Vecchio G, de Francisis V: Signaling through Ras is essential for ret oncogene - induced cell differentiation in $\mathrm{PC} 12$ cells. J Biol Chem 2000, 275:19297-19305.

5. Jones DA, Carlton DP, McIntyre TM, Zimmerman GA, Prescott SM: Molecular cloning of human prostaglandin endoperoxide synthase type II and demonstration of expression in response to cytokines. J Biol Chem 1993, 268:9049-9054.

6. Tsujii M, DuBois RN: Alterations in cellular adhesion and apoptosis in epithelial cells overexpressing prostaglandin endoperoxide synthase 2 . cell 1995, 3:493-501.

7. Fosslien E: Molecular pathology of cyclooxygenase-2-cancer-induced angiogenesis. Ann Clin Lab Sci 2001, 31:325-348.

8. Siironen P, Ristimäki A, Narko K, Nordling S, Louhimo J, Andersson S, Haapiainen R, Haglund C: VEGF-C and COX-2 expression in papillary thyroid cancer. Endocr Relat Cancer 2006, 13:465-473.

9. Soh EY, Duh Q-Y, Sobhi SA, Young DM, Epstein HD, Wong MG, Garcia YK, Min YD, Grossman RF, Siperstein AE, Clark OH: Vascular endothelial growth factor expression is higher in differentiated thyroid cancer than in normal or benign thyroid. J Clin Endocrinol Metab 1997, 82:3741-3747.

10. Hwang D, Scollard D, Byrne J, Levine E: Expression of cyclooxygenase-1 and cyclooxygenase-2 in human breast cancer. J Natl Cancer Inst 1998, 90:455-460.

11. van Rees BP, Saukkonen K, Ristimaki A, Polkowski W, Tytgat GN, Drillenburg P, Offerhaus GJ: Cyclooxygenase-2 expression during carcinogenesis in the human stomach. J Pathol 2002, 196:171-179.

12. Shirahama T, Sakakura C: Overexpression of cyclooxygenase-2 in squamous cell carcinoma of the urinary bladder. Clin Cancer Res 2001 7:558-561

13. Soslow RA, Dannenberg AJ, Rush D, Woerner BM, Khan KN, Masferrer J, Koki AT: COX-2 is expressed in human pulmonary, colonic and mammary tumors. Cancer 2000, 89:2537-2645.

14. Eberhat CE, Coffey RJ, Radhika A, Giardiello FM, Ferrenbach S, DuBois RN: Up-regulation of cyclooxygenase-2 gene expression in human colorectal adenomas and adenocarcinomas. Gastroenterology 1994, 107:1183-1188.

15. Zimmermann KC, Sarbia M, Weber AA, Borchard F, Gabbert HE, Schror K: Cyclooxygenase-2 expression in human esophageal carcinoma. Cancer Res 1999, 59:198-204.

16. Koga H, Sakisaka S, Ohishi M, Kawaquchi T, Taniquchi E, Sasatomi K, Harada M, Kusaba T, Tanaka M, Sata M: Expression of cyclooxygenase-2 in human hepatocellular carcinoma: relevance to tumor dedifferentiation. Hepatology 1999, 29:688-696.

17. Wolf $\mathrm{H}$, Saukkonen $\mathrm{K}$, Anttila S, Karjalainen A, Vainio $\mathrm{H}$, Ristimaki A: Expression of cyclooxygenase-2 in human lung carcinoma. Cancer Res 1998, 58:4997-5001.

18. Sano H, Kawahito Y, Wilder RL, Hashimoto A, Mukai S, Asai K, Kimura S, Kato $\mathrm{H}$, Kondo M, Hla T: Expression of cyclooxygenase-1 and -2 in human colorectal cancer. Cancer Res 1995, 55:3785-3789.

19. Okami J, Yamamoto H, Fujiwara Y, Tsujie M, Kondo K, Noura S, Oshima S: Overexpression of cyclooxygenase-2 in carcinoma of the pancreas. Clin Cancer Res 1999, 5:2018-2024.

20. Reddy BS, Hirose Y, Lubet R, Steele V, Kelloff G, Paulson S, Seibert K, Rao CV: Chemoprevention of colon cancer by specific cyclooxygenase-2 inhibitor, celecoxib, administered during different stages of carcinogenesis. Cancer Res 2000, 60:293-297.

21. Ziegler J: Early trials probe COX-2 inhibitors' cancer - fighting potential. J Natl Cancer Inst 1999, 91:1186-1187.

22. Chomczynski P, Sacchi N: Single-step method of RNA isolation by acid guanidinium thiocyanate-phenol-chloroform extraction. Anal Bioch 1987, 162:156-159

23. Brzezianska E, Cyniak-Magierska A, Sporny S, Pastuszak-Lewandoska D, Lewinski A: Assessment of cyclin D1 gene expression as prognostic factor in benign and malignant thyroid lesions. Neuroendocrinol Lett 2007, 28:341-350. 
24. Hamberger B, Gharib H, Melton $L$, Goellner JR, Zinsmeister AR: Fine needle aspiration biopsy of thyroid nodules: impact on thyroid practice and cost of care. Am J Med 1982, 73:381-384.

25. Ito Y, Yoshida H, Nakano K, Takmura Y, Miya A, Kobayashi K, Yokozawa T, Kuma K, Miyauchi A: Cyclooxygenase-2 expression in thyroid neoplasms. Histopathology 2003, 42:492-497.

26. Siironen P, Louhimo J, Nordling S, Ristimaki A, Maenpaa H, Haapiainen R, Haglund C: Prognostic factors in papillary thyroid cancer: an evaluation of 601 consecutive patients. Tumor Biol 2005, 26:57-64.

27. Garcia-Gonzales M, Abdulkader I, Vazquez Boquete A, Neo XM, Forteza J, Cameselle-Teijeiro J: Cyclooxygenase-2 in normal, hyperplastic and neoplastic follicular cells of the human thyroid gland. Virchows Arch 2005, 447:12-17.

28. Kajita S, Ruebel KH, Casey MB, Nakamura N, Lloyd RV: Role of COX-2, thromboxane $A 2$ synthase, and prostaglandin 12 synthase in papillary thyroid carcinoma growth. Mod Pathol 2005, 18:221-227.

29. Cornetta AJ, Russell JP, Cunnane M, Keane WM, Rothstein IL:

Cyclooxygenase-2 expression in human thyroid carcinoma and Hashimoto's thyroiditis. Laryngoscope 2002, 112:238-242.

30. Lee KJ, Jung YS, Kim WH, Yoon TI, Joo HJ, Soh EY: Cyclooxygenase-2 expression in human thyroid disease. J Endocrinol Invest 2008, 31:111-118.

31. Oshima M, Dinchuk JE, Kargman SL, Oshima H, Hancock B, Kwong E, Trzaskos JM, Evans JF, Taketo MT: Suppression of intestinal polyposis in Apc $\Delta 716$ knockout mice by inhibition of cyclooxygenase 2 (COX-2). Cell 1996, 5:803-809.

doi:10.1186/1756-6614-4-3

Cite this article as: Krawczyk-Rusiecka et al:: COX-2 expression in papillary thyroid carcinoma (PTC) in cytological material obtained by fine needle aspiration biopsy (FNAB). Thyroid Research 2011 4:3.

\section{Submit your next manuscript to BioMed Central} and take full advantage of:

- Convenient online submission

- Thorough peer review

- No space constraints or color figure charges

- Immediate publication on acceptance

- Inclusion in PubMed, CAS, Scopus and Google Scholar

- Research which is freely available for redistribution

Submit your manuscript at www.biomedcentral.com/submit
Biomed Central 